\title{
Design Ethnic-Math HOTS: Mathematics Higher Order Thinking Skill Questions Based On Culture and Local Wisdom
}

\author{
Fauzi Mulyatna ${ }^{1 *}$, Aritsya Imswatama ${ }^{2}$, \& Novia Dwi Rahmawati ${ }^{3}$ \\ ${ }^{1}$ Department of Mathematics Education, Universitas Indraprasta PGRI, Jakarta Selatan, Indonesia, 12530 \\ ${ }^{2}$ Department of Mathematics Education, Universitas Muhammadiyah Sukabumi, Jawa Barat, Indonesia, 43113 \\ ${ }^{3}$ Department of Mathematics Education, Universitas Hasyim Asy'ari Jombang, Jawa Timur, Indonesia, 61471 \\ *Corresponding author: fauzimulyatna@gmail.com I Phone Number: +628174108855
}

\section{ARTICLE HISTORY}

Received: 08 November 2020

Revised: 18 March 2021

Accepted: 20 April 2021

\section{KEYWORDS}

HOTS;

Ethnic-Mathematics ;

Culture;

\begin{abstract}
The design of HOTS Ethnic-Mathematics is the stage that has been intended in this study. This type of research is research and development (Research and Development) by producing results in the form of Mathematics Higher Order Thinking Skill (HOTS) questions based on culture and local wisdom (Ethnic-Math HOTS). The development model referred to by the researcher is the Analysis, Design, Development, Implementation and Evaluation (ADDIE) which is adapted into Analysis, Design, and Development (ADD). The conclusion of this paper is Mathematical problem designs that are integrated with local culture and local wisdom can be developed into questions that have a function to measure students' high-level abilities. High-level abilities that can be measured using these questions are analytical skills, evaluation skills and creative abilities. By completing questions related to the culture in the area around students, students will be more challenged and motivated to do it. In addition, it will increase students' knowledge about the local culture in the area.
\end{abstract}

This is an open access article under the CC-BY-SA license.

\section{INTRODUCTION}

The result of 2018 PISA Research (Program for International Student Assessment) stated that the average mathematics score of Indonesian students is still far below the average score of other countries (Kemdikbud, 2019). This should be an evaluation for stakeholders in the education field to immediately perform reflection and improvement. There are several studies regarding the causes of low PISA result, including low mathematical ability of students in solving mathematical reasoning problems. Besides, problem solving and students' rationalizing literacy skills in mathematics symbols are also low. One of the reasons is that current mathematics learning tends to be conventional and less contextual (Muhammad et al., 2019) .

The poor performance of Indonesian students in the PISA math test has prompted the Indonesian Ministry of Education and Culture to pay more attention to the integration of higher order thinking (HOT) skills (Tanudjaya \& Doorman, 2020). HOTS is a thought process where a person receives new knowledge and then processes it to be used in solving a problem. Therefore, HOTS requires students to do something about facts such as understanding, concluding, connecting with other facts and concepts, categorizing, manipulating, placing facts together with new and applied methods in finding a problem solution (Nugroho, 2019).

The current educational condition of students in learning mathematics using textbooks does not provide opportunities for students to learn mathematical procedures in solving context-based problems such as PISA (Wijaya, 2016).
In addition, Indonesia still uses low-level problems in the evaluation system, so that students' ability to solve non-routine problems is weak (Stacey, 2010).

Based on those explanations, an innovation in learning mathematics is needed, namely the development of a HOTS mathematical problem instrument and in accordance with real-world conditions. This is in line with the Regulation of the Minister of Education and Culture No. 68 of 2013 which supports innovative and contextual learning patterns. Thus, the learning process is expected to be interactive, fun, motivating, challenging and to create a single learning pattern becoming a multidisciplinary learning pattern.

The HOTS problem of mathematics based on culture and local wisdom (Ethnic-Math HOTS) can be a solution to solve these problems. This is in accordance with the opinion of Alfatin (2019) that by providing contextual and interesting questions from the problems around them, such as cultural-based questions in the area, it will make students more interested and also make it easier for students to understand and answer these questions (Alfatin, 2019). The reason is that ethnomathematics has an important role in mathematics learning in schools because ethnomathematics can bridge the background knowledge of students with mathematics lessons in schools (Imswatama \& Zultiar, 2019). Therefore, it is necessary to develop Mathematics Higher Order Thinking Skill (HOTS) questions based on culture and local wisdom (ethnic-Math HOTS) to improve students' 
problem-solving and reasoning ability. The purpose of this article is to provide a design and description of HOTS math problems based on culture and local wisdom.

\section{RESEARCH METHOD}

This research is a development research. Research and development is a process or steps to develop a new product or to improve an existing product that can be accounted for (Sukmadinata, 2008). This type of research is research and development (Research and Development) by producing results in the form of Mathematics Higher Order Thinking Skill (HOTS) questions based on culture and local wisdom (Ethnic-Math HOTS). The development model referred to by the researcher is the Analysis, Design, Development, Implementation and Evaluation (ADDIE) which is adapted into Analysis, Design, and Development (ADD). The stages that the research team has executed at this time are only at the design stage, meaning that the design of Mathematics Higher Order Thinking Skill (HOTS) questions based on culture and local wisdom (Ethnic-Math HOTS) will be consulted with experts consisting of assessment experts and material experts.

\section{RESULTS AND DISCUSSION}

\subsection{HOTS According to Bloom's taxonomy}

Talking about HOTS (Higher Order Thinking Skill), of course it cannot be separated from the taxonomy of educational goals introduced by Bloom, Elgelhart, Furst, Hill, \& Krathwohl (1956). In this taxonomy, especially in the cognitive realm, Bloom et al classify educational goals cognitively into six levels, namely: (a) Knowledge, (b) Comprehension, (c) Application, (d) Analysis, (e) Synthesis and (f) Evaluation (As'ari, 2019).

Analytical skills in higher-order thinking are the ability to find problems and then require activities to rebuild the problems, and identifies the most important and relevant elements of the problem, then continues to build appropriate relationships from the information that has been given. Furthermore, evaluation capability includes extensive planning, in which a plan is well-running and a criticize to it leads to the assessment of a product or operation based on external criteria and standards. Meanwhile, the creative ability in higher-order thinking is the ability to represent problems and to find alternative hypotheses needed and a plan to solve the given problems in which reasoning ability for thought processes and drawing a conclusion in the form of knowledge are necessary. Higher order thinking skills (HOTS) in this study include logic and reasoning skills, analysis, evaluation and creation (Rahmawati et al., 2018).

\subsection{Design questions to measure analytical} skills
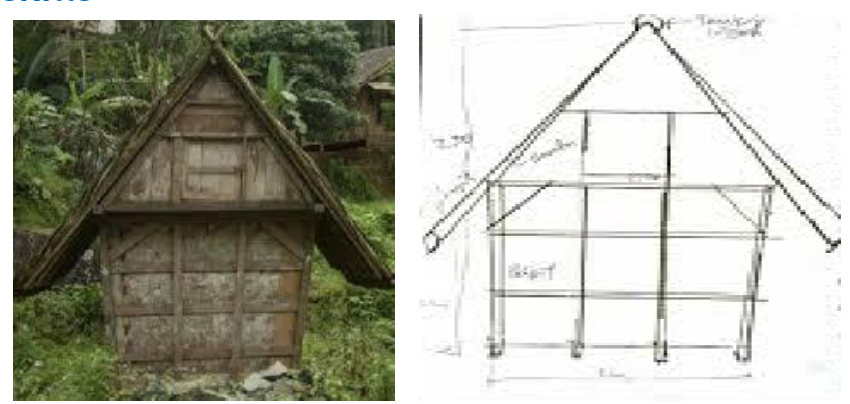

Leuit is one of the traditional buildings in West Java. Leuit functions as a storage area for rice that has the ability to withstand weather, pest and disease resistance and has a good air conditioning system so that dry rice can be stored for a long time. In general, a leuit with a length of $3 \mathrm{~m}$, a width of $1.5 \mathrm{~m}$ and a height of 1 meter can only accommodate 250 bunches of rice at most. What about the leuit which is $6 \mathrm{~m}$ long, $3 \mathrm{~m}$ wide and $2 \mathrm{~m}$ high, can it accommodate 750 bunches of rice? Explain your answer!

The question above is an example of HOTS questions to measure students' analytical and evaluation skills. Analyzing activity can be interpreted as an activity to break down information into its components to find possible relationships. In the questions above, students need to describe and look for the geometric shape that most closely matches the leuit building combined with the size information in the questions. Thus, if the geometric shape is known, the volume will be known.

Evaluating activities can be interpreted as activities in order to determine value, whether it is towards ideas, goods or methods based on established standards and criteria. The information conveyed from this question is that there are two buildings of different sizes, namely building A with a size of $3 \mathrm{x}$ $1.5 \times 1$ and building B with a size of $6 \times 3 \times 2$. Building A can clearly accommodate a maximum of 250 bunches of rice. By using the concept of same value comparison, students will find out and evaluate whether building B can accommodate 750 bunches of rice. From the results of these calculations, students can provide an explanation of the given questions.

The development of questions that are integrated with local culture and local wisdom is a learning that starts from what students know and don't know. This is in accordance with the principle of learning evaluation. By connecting with local culture, students will be more motivated to learn mathematics because they know the usefulness of mathematics in real life. It is hoped that the ethnic-math HOTS question design can produce students who not only think based on certain algorithms but also can be independent in developing their thoughts.

\subsection{Design questions to measure evaluation ability}

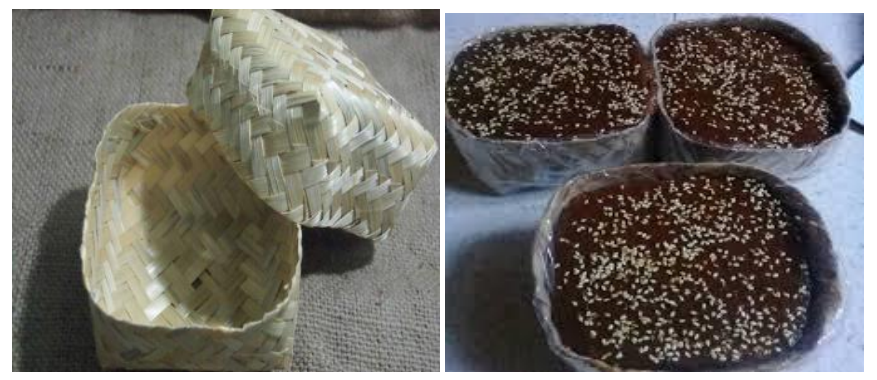

Figure 2. Besek

Besek is one of the works of bamboo craftsmen in Trenggalek, East Java. Besek is offered as an alternative to tackle plastic waste emergency. Rahma, the owner of typical Trenggalek Jenang Ketan, has besek in the shape of a beam. Besek has a volume of $5000 \mathrm{~cm}^{3}$. Tomorrow, it will be filled with Jenang Ketan from home industry production. However, Rahma has 3 different sizes of Jenang Ketan. Which one of these Jenang Ketan can fit in a besek?.

Table 1. Side length and price

Figure 1. Leuit 


\begin{tabular}{ccc}
\hline No & Side length & Price \\
\hline 1 & $15 \mathrm{~cm}$ & Rp 50.000 \\
\hline 2 & $17 \mathrm{~cm}$ & Rp 75.000 \\
\hline 3 & $20 \mathrm{~cm}$ & Rp 100.000 \\
\hline
\end{tabular}

The question above measures the HOTS of students on the evaluation indicators, especially the criticizing sub-indicators. The dimensions of knowledge measured in these questions are conceptual and metacognitive knowledge. Evaluating can be interpreted by providing an assessment of solutions, ideas, and methodologies using suitable criteria or existing standards to ascertain the value of their effectiveness or usefulness.

\subsection{Design questions to measure evaluation ability}
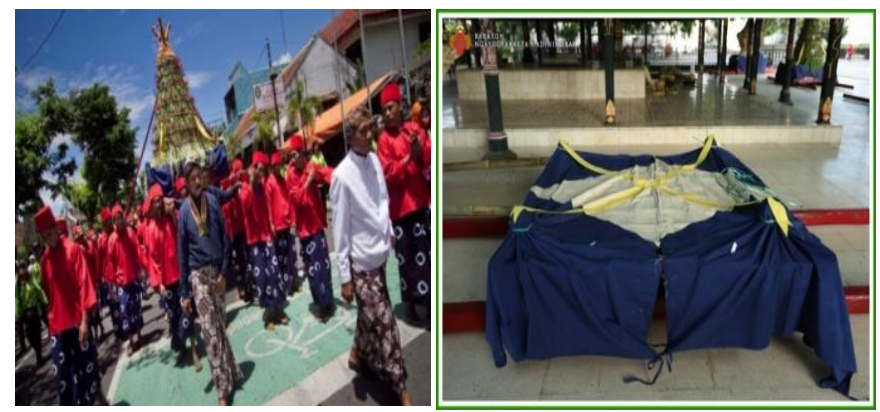

Figure 3. Grebeg Maulud

Grebeg Maulud is held to celebrate and to commemorate the birthday of the Prophet Muhammad SAW. The Grebeg ceremony begins with a parade of Keraton soldiers coming out completely with special weapons, pennants and musical instruments. At the end of the Gunungan parade, which is a pile of food that resembles a mountain and is always be the characteristic of Grebeg ceremonies, is brought out. Gunungan, which is usually a variety of agricultural products, is a prosperity symbol of the Yogyakarta Palace that will later be distributed to its people. Gunungan will be brought to the North Square and will be prayed together at the Gedhe Kauman mosque. After being prayed together, Gunungan is contested by the people who watched the Grebeg ceremony.

Gunungan kakung/jaler (male), is a cone-shaped form towering 2 meters with a diameter of 1.5 meters. The framework uses iron. This Gunungan consists of baderan, bendul, sangsangan, dengul, pelokan, and thengkilan kacang. Baderan is a cake made from rice flour which is shaped like a bader fish. The Gunungan Kakung itself is placed on the Jodhang, a wooden box that functions as a stretcher with a length of 4 meters. Like its name, Gunungan Kakung symbolizes the character of a Javanese warrior man. Measure the volume of the Jodhang outside the Gunungan Kakung, where each corner is tied with a Samir and a yellow cloth attached to the body of the Gunungan!

The question above measures students' HOTS on creating indicators, especially in the producing sub-indicators. The dimensions of knowledge measured in these questions are conceptual and metacognitive knowledge. Creating can be interpreted as the generalization of an idea or a way to solve a problem by organizing elements or parts into new structures that have never existed before.
The development of questions that are integrated with local culture and local wisdom is a learning that starts from what students know and don't know. This is in accordance with the principle of learning evaluation. By connecting with local culture, students will be more motivated to learn mathematics because they know the usefulness of mathematics in real life. It is hoped that the Ethnic-Math HOTS questions' design can produce students who not only think based on certain algorithms but also can be independent in developing their thoughts.

\section{CONCLUSION}

Mathematical problem designs that are integrated with local culture and local wisdom can be developed into questions that have a function to measure students' high-level abilities. High-level abilities that can be measured using these questions are analytical skills, evaluation skills and creative abilities. By completing questions related to the culture in the area around students, students will be more challenged and motivated to do it. In addition, it will increase students' knowledge about the local culture in the area.

\section{REFERENCES}

Alfatin, A. L. O. W. (2019). Pengembangan Soal HOTS Berbasis Budaya Jawa Timur Untuk Mengukur Penalaran Siswa SD. INDIKTIKA (Jurnal Inovasi Pendidikan Matematika), 2(1), 40-43.

As'ari, A. R. M. A. H. B. D. K. S. M. (2019). Mengembangkan HOTS (Higher Order Thinking Skill) melalui Matematika (M. D. K. S. M. Ali (ed.); 1st ed.). Universitas Negeri Malang. http:// www.ghbook.ir/index.php?name= مجمو عه مقالات دومين هم

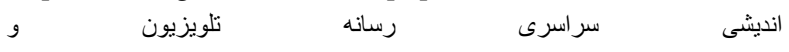
سكو لاريسم\&option=com_dbook\&task=readonline\&book_id=136 29\&page $=108 \&$ chkhashk $=03$ C706812F\&Itemid $=218 \&$ lang $=$ fa\& tmpl=component

Imswatama, A., \& Zultiar, I. (2019). Etnomatematika: Arsitektur Rumah Adat di Sukabumi sebagai Bahan Pembelajaran Matematika di Pendidikan Dasar. ARITHMETIC: Academic Journal of Math, 1(2), 119.

https://doi.org/10.29240/ja.v1i2.1007

Kemdikbud, P. W. (2019). Hasil PISA Indonesia 2018: Akses Makin Meluas, Saatnya Tingkatkan Kualitas. Kemdikbud. https://www.kemdikbud.go.id/main/blog/2019/12/hasil-pi sa-indonesia-2018-akses-makin-meluas-saatnya-tingkatkan-ku alitas

Muhammad, A. F. N., Marsigit, \& Soeharto. (2019). A case study of geometri literacy in elementary school through ethnomathematics at borobudur temple Indonesia. International Journal of Scientific and Technology Research, 8(10), 1041-1045.

Nugroho, R. . (2019). HOTS (kemampuan Berpikir Tingkat Tinggi, Konsep, Pembelajaran, Penilaian dan Soal-soal). In Kompas Gramedia. Kompas Gramedia.

Rahmawati, N. D., Amintoko, G., \& Faizah, S. (2018). Higher Order Thinking Skills of Mathematics Education Department Students of Hasyim Asy'ari University in Solving the Problem of Generator Function in Discrete Mathematics Lecture. ICMIs 2018, 1, 260-264. https:// doi.org/10.5220/0008520402600264 
Stacey, K. (2010). Mathematical and scientific literacy around the world. Journal of Science and Mathematics Education in Southeast Asia, 33(1), 1-16.

https:/ / pdfs.semanticscholar.org/c48a/333b0dc6f336e4150844 3b15d9e5d9761be9.pdf.

Sukmadinata, N. S. (2008). Metode Penelitian Pendidikan. PT.Remaja Rosdakarya.

Tanudjaya, C. P., \& Doorman, M. (2020). Examining higher order thinking in Indonesian lower secondary mathematics classrooms. Journal on Mathematics Education, 11(2), 277-300. https:// doi.org/10.22342/jme.11.2.11000.277-300

Wijaya, A. (2016). Students' information literacy: A perspective from mathematical literacy. Journal on Mathematics Education, 7(2), 73-82. https:// doi.org/10.22342/jome.v7i2.3532 